\title{
Foraging activities and diets of males and females in a haremic sandperch (Pisces: Pinguipedidae)
}

\author{
Mitsuhiko Sano
}

Department of Fisheries, Faculty of Agriculture, University of Tokyo, Yayoi, Bunkyo-ku, Tokyo 113, Japan

\begin{abstract}
Activity time allocations and diets of males and females in the pinguipedid fish Parapercis polyophthalma, which has haremic social groups dominated by single territorial males, were examined in shallow sandy areas at Iriomote Island, one of the Ryukyu Islands of Japan. During the day, males spent much less time foraging and more time engaging in social activities than did females, and actively patrolled the borders of their territories. Females, on the other hand, allocated most of their time to foraging and resting. The mean number of feeding bites taken during a 15 min observation per fish was ca 3 times greater in females than in males, although both sexes fed in the same places of sand and sandy rubble. These behavioral patterns demonstrated that males tend to be foraging-time minimizers, while females tend to be foraging-time maximizers. Despite the sex difference in feeding behavior, both sexes had similar diets consisting mainly of decapod crustaceans, including portunid crabs and alpheid shrimps. The high dietary overlap between foraging-time minimizers and maximizers sharing the same habitat and morphology can be explained using optimal foraging theory.
\end{abstract}

\section{INTRODUCTION}

Does foraging time or net energy gain differ between conspecific males and females in fishes? Schoener (1971), Hixon (1982) and Hoffman (1983) predicted 3 general patterns of sex-related foraging behavior (or net energy gain) in mating systems where total male parental investment is lower than female investment, particularly in species showing no parental care. First, males tend to minimize foraging time when their reproductive success is limited more by the amount of time spent in social and mating activities than by foraging activities. Second, males tend toward being foraging-time maximizers (= energy maximizers; Schoener 1971) if their reproductive success is primarily limited by energy available for sperm production. Third, females generally are foraging-time maximizers, especially when their reproductive success depends upon maximizing their energetic investments in gamete production or young. A significant sexual difference in time spent feeding is predicted, therefore, when males display the first pattern.

According to these predictions, a sexual difference in foraging time should be found in fish species with a social system based on male territoriality and a male-dominated harem (Hoffman 1983, Hixon 1987). Since single dominant males of such species can mate with almost all females within their territories (e.g. Neudecker \& Lobel 1982, Kuwamura 1984, Moyer 1984, Nakazono et al. 1985, Donaldson 1990), defence of the territories enable males to maximize mating success (Moyer \& Zaiser 1984, Thresher 1984, Moyer 1987). Males thus should spend more time protecting territories and maintaining social dominance over females, and less time foraging than do females (Hixon 1987). In the case of fishes in which males are not territorial and spawn in groups, foraging time is expected to be similar between the sexes. Both sexes maximize reproductive success by gaining greater energy and maximizing gamete production (Hoffman 1983).

The sandperch Parapercis polyophthalma (Pisces: Pinguipedidae) inhabits shallow coral-reef areas (Masuda et al. 1988) and is usually found in haremic social groups dominated by single territorial males (Sano 1990). In this system, one can expect that males are foraging-time minimizers and females are foraging-time maximizers. If so, does diet also differ be- 
tween the sexes? The primary goals of this study were to analyze the activity time allocations and stomach contents of male and female sandperch, and to ascertain whether sex differences in feeding time and diet exist.

Parapercis polyophthalma predominantly occurs on exposed sand plains of reef flats and channels at depths of 2 to $10 \mathrm{~m}$. It is sexually dichromatic and probably a protogynous hermaphrodite. Each male defends a territory within which 1 to 3 resident females smaller than the male forage and have individual non-overlapping home ranges. Territories are relatively large, with an average area of $193 \mathrm{~m}^{2}$ (Sano 1990). Pair spawning occurs within harems at dusk. Fertilized eggs are pelagic (Leis 1991), precluding parental care. Mature individuals have few or no predators in the daytime, suggesting that there is no effect of predation on their diurnal activity patterns.

\section{MATERIALS AND METHODS}

Field work was conducted in the fringing coral reef area of Amitori Bay $\left(24^{\circ} 20^{\prime} \mathrm{N}, 123^{\circ} 42^{\prime} \mathrm{E}\right)$ on the western side of Iriomote Island, one of the Ryukyu Islands of Japan, in October 1992, during the spawning season. This site has been mapped and described by Sano et al. (1987) and Sano (1990), respectively. Data collection involved 3 phases: (1) diurnal behavioral activity analysis; (2) collection of specimens for diet analysis; and (3) stomach content analysis. All underwater observations and specimen collection were made using a mask and snorkel between 10:00 and 15:00 h during the nonreproductive period of a day.

Diurnal activity analysis. Activities were observed on sandy flats of the reef flat zone, ranging in depth from 1 to $3 \mathrm{~m}$. A total of 40 observations of $15 \mathrm{~min}$ each were made on 20 males and 20 large females
(>140 $\mathrm{mm}$ in standard length, SL). Fish were chosen at random and observed once only. This species manifests sexual size dimorphism (males larger than females), so large females were most useful for intersexual comparisons of activity time allocation and diet to reduce the confounding effects of size and gender (e.g. Mittelbach 1981, Schmitt \& Holbrook 1984, Magurran 1986, Holbrook \& Schmitt 1992).

Four behavioral categories were identified, and each behavioral pattern was timed with an underwater stopwatch and tallied immediately on a plastic slate at its termination during each 15 min observation:

Foraging: Actual feeding and searching of the substratum for food were included in this category. During search time, the fish inspected the substratum while lowering its head, then quickly darted and consumed individual prey. The number of feeding bites was also counted in the $15 \mathrm{~min}$ period.

Social interactions: All intraspecific encounters, including approaches, frontal or lateral displays, chases, attacks, and flights were classified into this activity. No interspecific aggressive encounters were observed.

Swimming: This behavior was defined as an obvious movement from one location to another, with no clear function other than a change of location, e.g. a change of foraging locations, territory patrol by males, or movement from feeding sites to shelter.

Sitting: An immobile posture on the substratum, propping the anterior portion of the body on the pelvic fins, was included in this category.

Specimen collection. After the activity observations, 20 males and 20 large females (>140 mm SL) were collected from the sandy flats using a monofilament net. Immediately after collection, specimens were placed in $10 \%$ formalin and the stomach contents preserved by injecting concentrated formalin directly into the body cavity.

Table 1. Parapercis polyophthalma. Activity time allocations and numbers of feeding bites of males and females during a 15 min observation. Each individual was observed once. Values are mean \pm SD per 15 min per fish ( $n=20$ per sex). The Mann-Whitney $U$-test was performed to test differences between the sexes

\begin{tabular}{|c|c|c|c|c|}
\hline \multirow[t]{2}{*}{ Activity } & \multirow[t]{2}{*}{ Male } & \multirow[t]{2}{*}{ Female } & \multicolumn{2}{|c|}{ Significance } \\
\hline & & & $U$ & $\mathrm{p}$ \\
\hline \multicolumn{5}{|l|}{$\%$ of time allocated to: } \\
\hline Foraging & $4.0 \pm 1.71$ & $32.0 \pm 4.59$ & 400 & $<0.001$ \\
\hline Swimming & $28.0 \pm 6.14$ & $7.8 \pm 2.48$ & 400 & $<0.001$ \\
\hline \multicolumn{5}{|l|}{ Intraspecific social interactions } \\
\hline Male-male aggressive encounters & $0.3 \pm 1.04$ & - & - & - \\
\hline Male-female encounters & $0.6 \pm 0.50$ & $0.2 \pm 0.25$ & 305 & $<0.005$ \\
\hline Sitting & $67.1 \pm 6.28$ & $60.0 \pm 4.69$ & 316 & $<0.002$ \\
\hline Number of feeding bites & $3.15 \pm 1.53$ & $9.90 \pm 2.59$ & 395 & $<0.001$ \\
\hline
\end{tabular}


Stomach content analysis. Diet composition and gut fullness were determined. The standard length was measured for each specimen, and then the stomach was removed and opened. Food items from the stomach contents were sorted and identified under a lowpower binocular microscope. Each sorted item was blotted and weighed to the nearest $1 \mathrm{mg}$ (wet wt). Two methods were used to evaluate the relative importance of each prey item: (1) percentage occurrence of the item $_{i}$ and (2) percentage composition of each item by wet weight. The latter was calculated by dividing the sum total of the individual weight for the item by the total weight (Hyslop 1980).

To assess the degree of similarity in use of food between the sexes, I used the proportional similarity index (Schoener 1968, Linton et al. 1981):

$$
\alpha=1-0.5 \sum_{i=1}^{\mathrm{n}}\left|P_{\mathrm{x} i}-P_{\mathrm{y} i}\right|
$$

where $P_{x i}$ and $P_{y i}=$ the proportions by weight of the ith prey category in the diets of males $(\mathrm{x})$ and females $(y)$, and $n=$ total number of food categories in the diet. This index ranges from 0 (no overlap) to 1 (complete overlap).

The comparison of gut fullness between sexes was made using the actual stomach content weight of each fish, because the male and female specimens collected were close in size (cf. Daniels 1982, Durbin et al. 1983).

\section{RESULTS}

\section{Diurnal activity analysis}

The activity time allocations of male and female Parapercis polyophthalma differed significantly from each other (Table 1). Females spent much more time foraging than did males, whereas the amounts of time allocated to swimming, sitting and intraspecific social interactions by males were larger than those of females.

Males actively patrolled along the borders of their territories throughout the day. This patrol behavior involved sitting and facing outside territories, as well as swimming. During territorial surveillance, males also frequently visited and displayed to their harem females. Out of the 20 males observed, $16(80.0 \%)$ visited one or more females within their harems during the $15 \mathrm{~min}$ observation. Aggressive interactions between males were rare ( 3 out of 20 males) and restricted to border encounters between neighboring males. No encounters between females within harems were seen.

The number of feeding bites per 15 min was significantly greater in females than in males (Table 1).
Although the sexes showed conspicuous differences in foraging activity (Table 1), both took food from the same areas of sand and sandy rubble.

\section{Diet analysis}

Of the 20 males and the 20 females collected, all had stomachs containing food, including a variety of small benthic invertebrates and fish (Table 2). Decapod crustaceans dominated the diets of both sexes, accounting for $83.7 \%$ (males) and $84.8 \%$ (females) of the total diets by weight. Among decapods, portunid crabs were the most important prey item, followed by alpheid shrimps for both sexes. These 2 prey constituted $64.8 \%$ of the stomach content weight for males and $65.0 \%$ for females. Prey categories other than decapods were much less abundant $(<6 \%$ by weight) and less frequent ( $<26 \%$ by occurrence) in both male and female diets.

The dietary overlap value $(\alpha)$ between the sexes was high (0.824), indicating little sexual difference in diet. The proportions of the most important prey taxa, i.e. portunid crabs and alpheid shrimps, in the diets were remarkably similar between the genders (Table 2). The mean stomach content weight was significantly greater in females $\left(0.266 \mathrm{~g} \mathrm{stomach}^{-1} \pm 0.153 \mathrm{SD}\right)$ than

Table 2. Parapercis polyophthalma. Frequency of occurrence $(\% \mathrm{~F})$ and weight $(\% \mathrm{~W})$ of food items in diets of males and females. - : not consumed

\begin{tabular}{|c|c|c|c|c|}
\hline \multirow[t]{2}{*}{ Food item } & \multicolumn{2}{|c|}{ Male } & \multicolumn{2}{|c|}{ Female } \\
\hline & $\% \mathrm{~F}$ & $\% W$ & $\% \mathrm{~F}$ & $\% W$ \\
\hline \multicolumn{5}{|l|}{ Decapods } \\
\hline Portunid crabs & 55 & 39.4 & 65 & 39.4 \\
\hline Parthenopid crabs & 10 & 5.5 & 15 & 2.0 \\
\hline Xanthid crabs & 15 & 3.7 & 10 & 2.4 \\
\hline Majid crabs & 15 & 3.4 & 10 & 1.9 \\
\hline Porcellanid crabs & 5 & 2.7 & - & - \\
\hline Galatheid crabs & 15 & 1.8 & 35 & 4.7 \\
\hline Alpheid shrimps & 40 & 25.4 & 55 & 25.6 \\
\hline Hippolytid shrimps & 10 & 1.8 & 5 & 8.8 \\
\hline Polychaetes & 20 & 5.5 & 15 & 0.5 \\
\hline Gastropods & 20 & 4.4 & 15 & 4.7 \\
\hline Fish & 15 & 1.4 & 20 & 5.4 \\
\hline Stomatopods & 5 & 0.9 & 20 & 2.8 \\
\hline Sipunculids & 5 & 0.5 & 10 & 0.5 \\
\hline Pelecypods & 5 & 1.8 & - & - \\
\hline Echinoids & 5 & 1.8 & - & - \\
\hline Gammaridean amphipods & - & - & 25 & 0.5 \\
\hline Euphausids & - & - & 10 & 0.4 \\
\hline Ophiuroids & - & - & 5 & 0.4 \\
\hline Number of fish examined & \multicolumn{2}{|c|}{20} & \multicolumn{2}{|c|}{20} \\
\hline Standard length (mm) & \multicolumn{2}{|c|}{$158-182$} & \multicolumn{2}{|c|}{$141-163$} \\
\hline
\end{tabular}


in males $(0.109 \pm 0.094 ;$ Mann-Whitney $U$-test, $U=$ 343, $\mathrm{p}<0.001)$.

\section{DISCUSSION}

My data on activity time allocation in male and female Parapercis polyophthalma were concordant with the predictions of Schoener (1971), Hixon (1982, 1987) and Hoffman (1983) in that the amounts of time allocated to foraging and nonforaging activities can be sex related. Males spent much less time feeding and more time on territorial and social activities than did females, because males would be able to gain increased mating success by defending their territories, maintaining social dominance over females, and securing mates. Females spent much more time feeding, likely because of limitation of female reproductive success by available energy for gamete production and growth.

Both males and females spent a large proportion of their time (67 and $60 \%$, respectively) sitting in the apparent absence of predators. In this sitting time males may actually be scanning for conspecific competitors and females may be resting and digesting between successive feeding bouts.

These behavioral patterns demonstrate that males tend to be foraging-time minimizers and females to be foraging-time maximizers. Among fishes, similar results were recognized in the haremic labrid Bodianus rufus (Hoffman 1983) and pomacanthid Centropyge interruptus (Moyer 1987), and in nonharemic territorial labrids $B$. diplotaenia (Hoffman 1983) and Tautogolabrus adspersus (Green et al. 1984).

The mean weight of food per stomach in females was 2.4 times more than that in males. Diets were similar between the sexes, as the dietary overlap value showed. This suggests that the sexual difference in net energy gain also occurred in the sandperch, with males gathering lower net energy than females.

The phenomenon that the diet of males (foragingtime minimizers) was fairly close to that of females (foraging-time maximizers) can be explained using optimal foraging theory (Schoener 1971, Pyke et al. 1977, Pyke 1984, Stephens \& Krebs 1986). Based on this theory, any individual should obtain optimal diet by maximizing the ratio of net energy input to foraging time. To maximize the ratio and minimize time spent feeding, foraging-time minimizers should take prey for which searching and handling time is lowest, assuming net energy input is identical among different prey items. When searching and handling time for each item is equal, on the other hand, they should consume food with highest energy content to satisfy some fixed daily energy requirement as quickly as possible. For- aging-time maximizers also can increase the ratio and net energy gains during a given time period in these 2 ways. As a result, both types of foragers start to hunt the prey item having the highest value of the ratios, and their diets are expected to be similar if the 2 foragers share the same habitat and morphology, as do males and females of Parapercis polyophthalma (cf. Thorp et al. 1989, Sakashita 1992). In essence, therefore, the primary difference between the 2 foraging types may be the relative proportion of available time spent feeding (Hixon 1980, 1982).

Green et al. (1984) found a dietary difference between territorial males and females in the labrid fish Tautogolabrus adspersus, although males were foraging-time minimizers relative to females and both sexes shared the same habitat and morphology (Pottle \& Green $1979 a, b)$. These findings contrast with my results and the prediction arising from optimal foraging theory. I cannot account for this discrepancy. Far more detailed investigations of diet for males and females of fishes whose foraging behavior varies by sex are required in order to see the level of agreement between the prediction and observed results.

Acknowledgements. I am grateful to Makoto Shimizu for helpful suggestions and cooperation. I also thank Hiroyuki Yokochi, Hiroyoshi Kohno, Nagahiro Nakazato, Hisatoshi Baba, and the Okinawa Regional Research Center, Tokai University, for assisting in the field work. Comments on the manuscript from Mark A. Hixon, Jack T Moyer, Charles E. Birkeland, and 3 anonymous reviewers, and discussions with Yutaka Kurita, Tetsuo Kuwamura, Katsuki Nakai, Shigeru Nakano, and Mikio Noda were very helpful.

\section{LITERATURE CITED}

Daniels, R. A. (1982). Feeding ecology of some fishes of the Antarctic Peninsula. Fish. Bull. U.S. 80: 575-588

Donaldson, T. J. (1990). Reproductive behavior and social organization of some Pacific hawkfishes (Cirrhitidae). Jap. J. Ichthyol. 36: 439-458

Durbin, E. G., Durbin, A. G., Langton, R. W., Bowman, R. E. (1983). Stomach contents of silver hake, Merluccius bilinearis, and Atlantic cod, Gadus morhua, and estimation of their daily rations. Fish. Bull. U.S. 81:437-454

Green, J. M., Martel, G., Martin, D. W. (1984). Comparisons of the feeding activity and diets of male and female cunners Tautogolabrus adspersus (Pisces: Labridae). Mar. Biol. 84 $7-11$

Hixon, M. A. (1980). Food production and competitor density as the determinants of feeding territory size. Am. Nat. 115 $510-530$

Hixon, M. A. (1982). Energy maximizers and time minimizers: theory and reality. Am. Nat. 119: 596-599

Hixon, M. A. (1987). Territory area as a determinant of mating systems. Am. Zool. 27: 229-247

Hoffman, S. G. (1983). Sex-related foraging behavior in sequentially hermaphroditic hogfishes (Bodianus spp.). Ecology 64: 798-808

Holbrook, S. J., Schmitt, R. J (1992). Causes and conse- 
quences of dietary specialization in surfperches: patch choice and intraspecific competition. Ecology 73: 402-412

Hyslop, E. J. (1980). Stomach contents analysis - a review of methods and their application. J. Fish Biol. 17: 41 I-429

Kuwamura, $T$ (1984). Social structure of the protogynous fish Labroides dimidiatus. Publs. Seto mar. biol. Lab. 29: $117-177$

Leis, J. M. (1991). The pelagic stage of reef fishes: the larval biology of coral reef fishes. In: Sale, P. F. (ed.) The ecology of fishes on coral reefs. Academic Press, San Diego, p. $183-230$

Linton, L. R., Davies, R. W., Wrona, F. J. (1981). Resource utilization indices: an assessment. J. Anim. Ecol. 50: 283-292

Magurran, A. E. (1986). Individual differences in fish behaviour. In: Pitcher, T. J. (ed.) The behaviour of teleost fishes. Croom Helm, London, p. 338-365

Masuda, H., Amaoka, K., Araga, C., Uyeno, T., Yoshino, T (eds.) (1988). The fishes of the Japanese Archipelago, 2nd edn. Tokai Univ. Press, Tokyo (English text and plates)

Mittelbach, G. G. (1981). Foraging efficiency and body size: a study of optimal diet and habitat use by bluegills. Ecology 62: $1370-1386$

Moyer, J. T (1984). Social organization and reproductive behavior of ostraciid fishes from Japan and the western Atlantic Ocean. J. Ethol. 2: 85-98

Moyer, J. T (1987). Social organization and protogynous hermaphroditism in marine angelfishes (Pomacanthidae). In: Nakazono, A., Kuwamura, T. (eds.) Sex change in fishes. Tokai Univ. Press, Tokyo, p. 120-147 (in Japanese)

Moyer, J. T., Zaiser, M. J. (1984). Early sex change: a possible mating strategy of Centropyge angelfishes (Pisces: Pomacanthidae). J. Ethol. 2: 63-67

Nakazono, A., Nakatani, H., Tsukahara, H. (1985). Reproductive ecology of the Japanese reef fish, Parapercis snyderi. Proc. 5th int. coral Reef Congr. 5: 355-360

Neudecker, S., Lobel, P. S. (1982). Mating systems of chaetodontid and pomacanthid fishes at St. Croix. Z. Tierpsychol. 59: $299-318$

Pottle, R. A., Green, J. M. (1979a). Field observations on the

This article was presented by C. Birkeland, Mangilao, Guam reproductive behaviour of the cunner, Tautogolabrus adspersus (Walbaum), in Newfoundland. Can. J. Zool. 57 : $247-256$

Pottle, R. A., Green, J. M. (1979b). Territorial behaviour of the north temperate labrid, Tautogolabrus adspersus. Can. J Zool. 57: $2337-2347$

Pyke, C. H. (1984). Optimal foraging theory: a critical review. A. Rev. Ecol. Syst. 15: 523-575

Pyke, G. H., Pulliam, H. R., Charnov, E. L. (1977). Optimal foraging: a selective review of theory and tests. Q. Rev. Biol 52: $137-154$

Sakashita, H. (1992). Sexual dimorphism and food habits of the clingfish, Diademichthys lineatus, and its dependence on host sea urchin. Environ. Biol. Fish. 34: 95-101

Sano, M. (1990). Patterns of habitat and food utilization in two coral-reef sandperches (Mugiloididae): competitive or noncompetitive coexistence? J. exp. mar. Biol. Ecol. 140: $209-223$

Sano, M., Shimizu, M., Nose, Y. (1987). Long-term effects of destruction of hermatypic corals by Acanthaster planci infestation on reef fish communities at Iriomote Island Japan. Mar. Ecol. Prog. Ser. 37: 191-199

Schmitt, R. J., Holbrook, S. J. (1984). Ontogeny of prey selection by black surfperch Embiotoca jacksoni (Pisces. Embiotocidae): the roles of fish morphology, foraging behavior, and patch selection. Mar. Ecol. Prog. Ser. 18 225-239

Schoener, T. W. (1968). The Anolis lizards of Bimini: resource partitioning in a complex fauna. Ecology 49: 704-726

Schoener, T. W. (1971). Theory of feeding strategies. A. Rev. Ecol. Syst. 2: 369-404

Stephens, D. W., Krebs, J. R. (1986). Foraging theory. Princeton Univ. Press, Princeton

Thorp, J H., Goldsmith, L. D., Polgreen, J. A., Mayer, L. M. (1989). Foraging patterns of nesting and nonnesting sunfish (Centrarchidae: Lepomis auritus and $L$ gibbosus). Can. J. Fish. Aquat. Sci. 46: 1342-1346

Thresher, R. E. (1984). Reproduction in reef fishes. T F. H Publications, Neptune City

Manuscript first received: January 29, 1993

Revised version accepted: May 25, 1993 